\title{
Fingerprinting Gold Leaf from Portuguese Baroque Altarpieces
}

\author{
A. Bidarra, ${ }^{*}$ J. Coroado, ${ }^{* *}$ and F. Rocha* \\ * Geobiotec/Departamento de Geociências - Campus Universitário de Santiago - 3810-193 Aveiro, \\ Portugal, bidarra.ana@gmail.com, tavares.rocha@ua.pt \\ ** Departamento de Conservação e Restauro, Instituto Politécnico de Tomar - Quinta do Contador, \\ Estrada da Serra - 2300-313 Tomar, Portugal, jcoroado@ipt.pt
}

The Baroque period was one of the most prolific periods in Portuguese art. One of its most magnificent expressions took the shape of gilded woodcarved altarpieces covering partially or totally the interior of the churches, in complex and structured architectures, working alone or in association with ceramic tiles (azulejos) or paintings [1]. This style comprised the last quarter of the $17^{\text {th }}$ century until the first half of the $18^{\text {th }}$ century and can be divided in two major periods: Barroco Nacional (c. 1680 - 1729) and Barroco Joanino (c. 1729 - 1750) [2].

Despite the existence of several works on the study of these art forms, they are mainly focused on treatises and orders from the manufacturing period or in art history relations. This study, however, aims to provide a new approach to the analysis of this architectural art, by focusing not only in these aspects but also in the study of the gol d leaf, in or der to identify a distinct fingerprint for each altarpiece. The gold provenance relations, circulation and compositional and textural aspects structure and micro structural, - are some of the factors that will be considered.

The samples were collected from some of the most representative Portuguese Baroque altarpieces, located in different churches in Portuguese northwest.

The qualitative and semi-quantitative analysis of the samples were performed by optical microscopy $(\mathrm{OM})$ of cross-sections using reflected and polarised light, by scanning electron microscopy (SEM) in combination with energy dispersive spectroscopy (EDS) [3] and by Inductively coupled plasma mass spectrometry (ICP-MS) [4].

The OM and SEM t echniques revealed the presence of im portant common features related to physical aspects such as surface $m$ orphology, extreme thinness and uniformity. EDS results confirmed the purity of the gold that was used, with more than 22 carats (Table 1) and the presence of a gold/silver/copper alloy. Due to ED S detection limits, peak overlapping and bremsstrahlung background it wasn't possible to identify the trace elements [5]. The ICP-MS technique provided these results revealing the presence of several elements in very low concentrations such has As, $\mathrm{Cr}$, $\mathrm{Ga}, \mathrm{Hg}$ and $\mathrm{Pd}$. These elements are essential to the characterisation and typification of the gold, but can also reveal technological aspects of the gold leaf production and on the gold origin; the presence of mercury, could point to the use of an amalgamation process. 
The OM and SEM-EDS analysis allowed identifying some common features in the different samples, regarding not only physical but also technological and elemental aspects, such as t he presence of a traditional gilding, with three distinguished layers - ground, bole and gold - and the presence of a very pure gold, with more than 22 carats. This technique al so provided an accurate determination of the major elements in the gold alloy and on the other layers (Figure 1). Through ICP-MS, it was possible to identify trace elements in the gold and also to have a new insight into the manufacturing process, due to the presence of mercury in the samples. However, the study of Baroque altarpieces gold leaf is still a w ork in progress. The performed exams revealed a new insight into the gilding technique and provided a new perspective in the analysis of these coatings, but some limitations were detected, mainly due to the fact that the samples are very small approximately $1 \mathrm{~mm}^{2}$ and less than $2 \mu \mathrm{m}$ thickness for the gold leaf - but also due to equipment limitations, namely the detection limits. Other exams are now in order such has X-ray fluorescence using Synchrotron radiation (XRF-SR) and X-ray diffraction (XRD). [6]

TABLE 1. Concentration in relative percentage of the alloy composition and gold carat.

\begin{tabular}{|l|l|l|l||l|}
\cline { 2 - 5 } \multicolumn{1}{c|}{} & \multicolumn{1}{l}{$\%$} \\
\hline Samples & $\mathrm{Au}$ & $\mathrm{Ag}$ & $\mathrm{Cu}$ & Carats \\
\hline SB & 91,99 & 2,9 & 5,11 & 22,08 \\
\hline SC & 94,91 & 0,91 & 4,18 & 22,78 \\
\hline SF & 91,65 & 4,41 & 3,94 & 22,00 \\
\hline AV & 93,41 & 4,43 & 2,16 & 22,42 \\
\hline
\end{tabular}

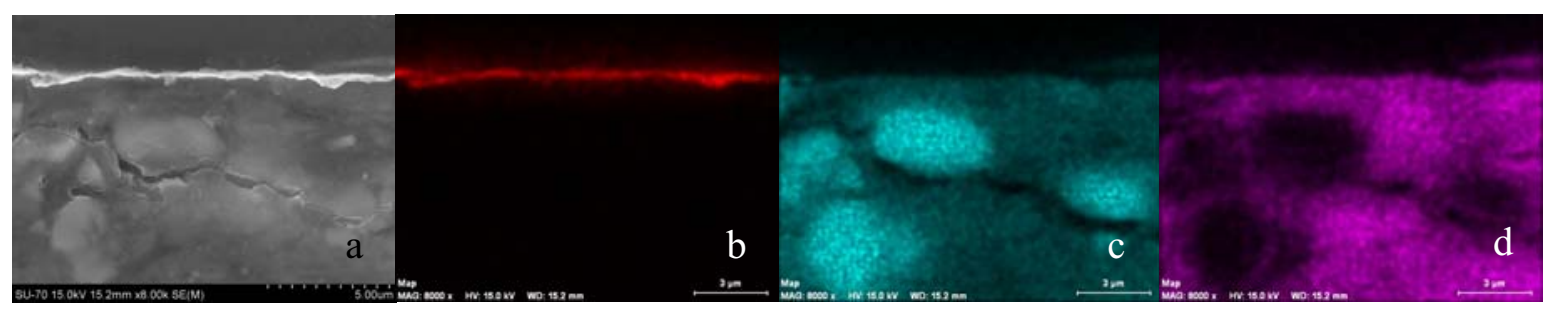

FIG. 1. SEM i mage (a) and EDS mapping of the sample SB cross-section: b) gold, c) silica and d) aluminium $(8000 \mathrm{x})$.

\section{References}

[1] N. M. Ferreira-Alves, A Arte da Talha no Porto na Época Barroca. Artistas e clientela. Materiais e técnica. Vol.I e II. Arquivo Histórico, Câmara Municipal do Porto (1989).

[2] R. Smith, A talha em Portugal. Livros Horizonte, Lisboa (1962).

[3] A. Bidarra, J. Co roado, F. Rocha, "An app roach to the study of gold leaf from a Baroque altarpiece", Sculpture, polychromy and architectural decoration group, ICOM-CC, Triennium 2008-2011, Newsletter 2 (2010): 9-11.

[4] M. F. Guerra, Fingerprinting ancient gold with proton beams of different energies. Nuclear Instruments and Methods in Physics Research, Serie B, 226 (2004): 185-198.

[5] A. Bidarra, J. Cor oado, F. Rocha, "Gold leaf analysis of thr ee Porto baroque altarpieces", ArcheoSciences, Revue d'Archéométrie, 33 (2009): 417-422.

[6] Portuguese Foundation for Science and Technology (FCT) for PhD grant FRH/BD/38593/2007. 